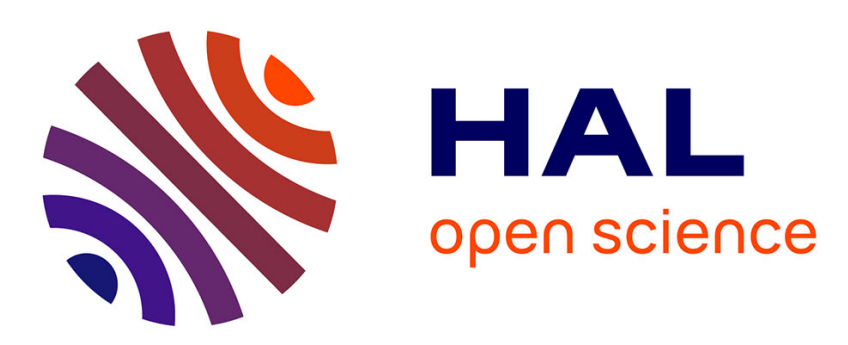

\title{
Comparison of Bond Dissociation Energies of Dormant Species Relevant to Degenerative Transfer and Atom Transfer Radical Polymerization
}

Krzysztof Matyjaszewski, Rinaldo Poli

\section{- To cite this version:}

Krzysztof Matyjaszewski, Rinaldo Poli. Comparison of Bond Dissociation Energies of Dormant Species Relevant to Degenerative Transfer and Atom Transfer Radical Polymerization. Macromolecules, 2005, 38 (19), pp.8093-8100. 10.1021/ma0512049 . hal-03277809

\author{
HAL Id: hal-03277809 \\ https://hal.science/hal-03277809
}

Submitted on 6 Jul 2021

HAL is a multi-disciplinary open access archive for the deposit and dissemination of scientific research documents, whether they are published or not. The documents may come from teaching and research institutions in France or abroad, or from public or private research centers.
L'archive ouverte pluridisciplinaire HAL, est destinée au dépôt et à la diffusion de documents scientifiques de niveau recherche, publiés ou non, émanant des établissements d'enseignement et de recherche français ou étrangers, des laboratoires publics ou privés. 


\section{Comparison of Bond Dissociation Energies of Dormant Species Relevant to Degenerative Transfer and Atom Transfer Radical Polymerization}

Krzysztof Matyjaszewski ${ }^{\mathrm{a}}$ and Rinaldo Poli ${ }^{\mathrm{b}}$

${ }^{a}$ Department of Chemistry, Carnegie Mellon University, 4400 Fifth Avenue, Pittsburgh, PA 15213, USA

${ }^{\mathrm{b}}$ Laboratoire de Chimie de Coordination, UPR CNRS 8241, 205 Route de Narbonne, 31077 Toulouse Cedex, France 


\section{Summary}

Density functional calculations are reported for the Bond Dissociation Energy (BDE) of a number of dithioacetates, $\mathrm{CH}_{3} \mathrm{C}(\mathrm{S}) \mathrm{S}-\mathrm{R}$ and selected dithiobenzoates, $\mathrm{PhC}(\mathrm{S}) \mathrm{S}-\mathrm{R}$, of relevance to Reversible Addition-Fragmentation Transfer (RAFT) controlled radical polymerization. In comparison with previously reported calculations (M. B. Gillies, K. Matyjaszewski, P.-O. Norrby, T. Pintauer, R. Poli, P. Richard, Macromolecules 2003, 36, 8551-8559) at the same level on corresponding $\mathrm{R}-\mathrm{X}$ systems ( $\mathrm{X}=\mathrm{Cl}, \mathrm{Br}, \mathrm{I}, \mathrm{N}_{3}$, $\mathrm{S}_{2} \mathrm{CNMe}_{2}$ ), the result reveal significant steric and polar effects on the BDE. Particularly bulky $\mathrm{R}$ grous $\left(t \mathrm{Bu}, \mathrm{C}\left(\mathrm{CH}_{3}\right)_{2} \mathrm{COOMe}\right)$ yield relatively weaker $\mathrm{R}-\mathrm{S}_{2} \mathrm{CZ}(\mathrm{Z}=\mathrm{Me}, \mathrm{Ph})$ bonds, such that the radical transfer process to $\mathrm{R}^{\prime}-\mathrm{S}_{2} \mathrm{CZ}$ where $\mathrm{R}^{\prime}$ is less sterically encumbering (e.g. $\mathrm{CH}\left(\mathrm{CH}_{3}\right) \mathrm{COOMe}$ ) is less favourable, when compared to the same transfer to R'-Cl (or R'-Br). As indicated by an analysis of DFT computed Natural Charges, electronegative substituents in the $\alpha$ position of the R group (F, OMe, OAc, and also multiple substitution with $\mathrm{Cl}$ atoms) reinforce the ionic component of the $\mathrm{R}-\mathrm{X}$ bond when $\mathrm{X}$ is a more electronegative group (i.e. $\mathrm{Cl}, \mathrm{Br}$ ) relative to $\mathrm{S}_{2} \mathrm{CZ}$. Therefore, transfer of these radicals is also disfavoured for $\mathrm{R}^{\prime}-\mathrm{S}_{2} \mathrm{CZ}$ relative to $\mathrm{R}$ '- $\mathrm{Cl}$ or $\mathrm{R}$ '- $\mathrm{Br}$. These effects rationalize experimental observations and can be used as a guiding tool for the rational design of ATRP initiators and RAFT transfer agents. 


\section{Introduction}

Controlled/living radical polymerization (CRP) is among the most rapidly developing areas of polymer science. ${ }^{1,2}$ It enables preparation of many previously inaccessible macromolecular structures and new generations of advanced materials. .,3-8 $^{1}$ The degree of precision of macromolecular engineering and control of chain topology, composition and functionality depends on the contribution of chain breaking reactions as well as on efficiency of initiation. Therefore, it is of paramount importance not only to minimize contributions of irreversible chain transfer and chain termination but also to maximize initiation and cross-propagation efficiency in the synthesis of segmented copolymers.

All of the CRP systems employ dynamic equilibration between dormant species and growing radicals which exchange either via reversible activation/deactivation cycles or through the degenerative transfer process. ${ }^{1,9}$ The overall rate of propagation depends on the rate constant of propagation and on the proportion of active species, which is related to the corresponding equilibrium constant. The absolute values of the equilibrium constants and rate constants of the constituting reactions can be determined in various ways, from model studies, polymerization kinetics, spectroscopic studies, etc. ${ }^{10-22}$ These values depend very strongly on the structure of the catalyst and the capping species, and also on the structure of the propagating radicals.

We have recently reported values of the absolute and relative equilibrium constants for the dissociation of alkyl (pseudo)halides (R-X) with structures relevant to dormant/propagating species in atom transfer radical polymerization (ATRP) and other 
CRP processes. ${ }^{23} \mathrm{We}$ found tremendous differences in the bond dissociation energies (BDE) between various alkyl halides. For example, relative values of the ATRP equilibrium constants for $\mathrm{R}-\mathrm{Cl}$ systems modeling chain ends in polymerization of ethylene, vinyl acetate, methyl acrylate, styrene and acrylonitrile were $\mathrm{K}=4 \cdot 10^{-10}, 3 \cdot 10^{-7}$, 1,16 , and $2 \cdot 10^{3}$, respectively. Thus, taking into account the corresponding rate constants of propagation, one could estimate that if the time needed to accomplish a given conversion of methyl acrylate with a given ATRP catalytic system were $1 \mathrm{~h}$, the same conversion would be reached after $0.5 \mathrm{~s}$ for acrylonitrile, $11 \mathrm{~h}$ for styrene, 15 years for vinyl acetate, and 170,000 years for ethylene, under otherwise identical conditions. Therefore, entirely different conditions and catalysts must be used for successful ATRP of acrylonitrile, vinyl acetate, and ethylene than for styrene and methyl acrylate.

A conclusion from the previous studies was that the BDE dramatically depends on the nature of $\mathrm{X}$, in the order $\mathrm{Cl}>\mathrm{Br}>\mathrm{N}_{3}>\mathrm{S}_{2} \mathrm{CNMe}_{2} \approx \mathrm{I}$. For instance, $\Delta \mathrm{G}$ values for the methyl 2-(pseudo)halopropionate derivatives are $60.4 \mathrm{kcal} / \mathrm{mol}(\mathrm{Cl}), 51.8 \mathrm{kcal} / \mathrm{mol}(\mathrm{Br})$, $47.5 \mathrm{kcal} / \mathrm{mol}\left(\mathrm{N}_{3}\right), 32.4 \mathrm{kcal} / \mathrm{mol}\left(\mathrm{S}-\mathrm{C}(\mathrm{S})-\mathrm{NMe}_{2}\right)$, and $29.0 \mathrm{kcal} / \mathrm{mol}(\mathrm{I})$. The relative values of $\Delta \Delta \mathrm{G}$ for selected pairs of $\mathrm{R}$ groups are little dependent on the nature of $\mathrm{X}$, e.g. the differences between methyl 2-halopropionates and 1-phenylethyl halides were $~ 1.6$ $\mathrm{kcal} / \mathrm{mol}$ for $\mathrm{Cl}$ and $\mathrm{Br}, 2 \mathrm{kcal} / \mathrm{mol}$ for $\mathrm{N}_{3}, \sim 2.6 \mathrm{kcal} / \mathrm{mol}$ for $\mathrm{I}$, and $\sim 2.8 \mathrm{kcal} / \mathrm{mol}$ for $\mathrm{S}_{2} \mathrm{CNMe}_{2}$. However, a significant difference was observed for $\mathrm{R}=\mathrm{t}$-butyl vs. $\mathrm{R}=2$ propionate. For chloride, bromide and iodide the relative differences were quite large ( $\Delta \Delta \mathrm{G} \sim 8 \mathrm{kcal} / \mathrm{mol}$, corresponding to the ratio of the bond dissociation equilibrium constants $\mathrm{K}_{\mathrm{tB}} / \mathrm{K}_{\mathrm{PR}} \sim 10^{-6}$ ), see Scheme 1 . However, for $\mathrm{X}=\mathrm{S}_{2} \mathrm{CMe}_{2}$, the difference was much smaller $(\Delta \Delta \mathrm{G}=0.9 \mathrm{kcal} / \mathrm{mol}$, corresponding to the ratio of the equilibrium 
constants $\mathrm{K}_{\mathrm{tB}} / \mathrm{K}_{\mathrm{PR}} \sim 0.2$ !). This indicates that $\mathrm{BDE}$ for various $\mathrm{X}$ may sometimes specifically depend on R.

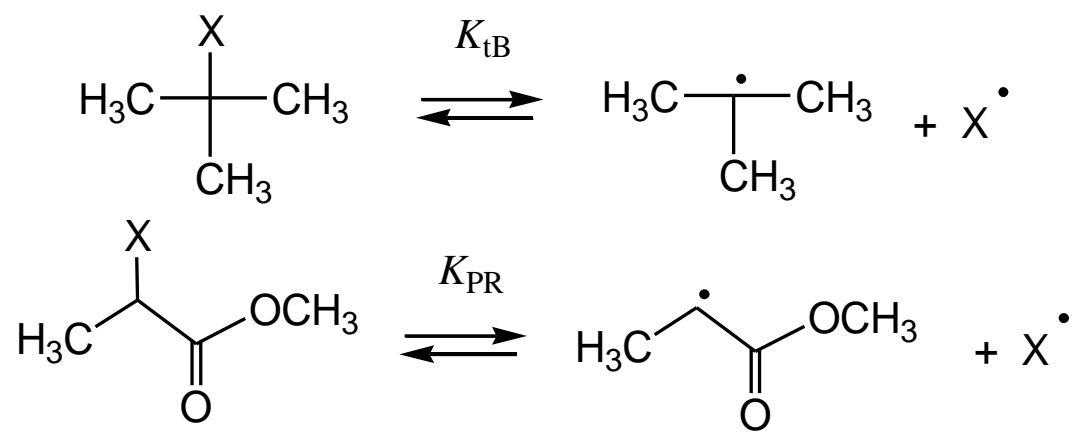

Scheme 1

In this paper we present results of calculations for the BDE for a variety of alkyl dithioacetates and for a few selected examples of dithiobenzoates, relevant to reversible addition-fragmentation chain transfer (RAFT) systems, and we compare these values with those previously reported for similar alkyl (pseudo)halides. The BDE values help to understand the effect of $\mathrm{R}$ and $\mathrm{X}$ structures on the bond strength for the homolytic cleavage (catalyzed or not). They are also important to understand the relative equilibrium position in the exchange reactions during CRP copolymerization processes. It is important to highlight parallel work focused on the substituent effects on the thermodynamics and rates of the radical addition and reverse fragmentation processes involving dithiocarbamate and other substrates. ${ }^{24-30}$ In our study, we do not address the individual addition and fragmentation phenomena (i.e. we do not examine the relative energy of the radical addition product), but rather examine the overall radical transfer equilibrium process on the basis of bond dissociation energy calculations, using a wider range of radicals that are closer models of the real polymerization processes. Our study 
reveals that the trend of $\mathrm{BDE}$ for $\mathrm{R}-\mathrm{SC}(\mathrm{S}) \mathrm{Me}$ does not perfectly parallel those previously established for analogous $\mathrm{R}-\mathrm{X}$ series $(\mathrm{X}=\mathrm{Cl}, \mathrm{Br})$, and it brings to light the steroelectronic reasons for the observed discrepancies.

\section{Computational details}

All DFT calculations were run with Gaussian03, ${ }^{31}$ using the B3P86 functional. ${ }^{32}$ The 6-31G** basis set was used for all $\mathrm{H}, \mathrm{C}, \mathrm{N}, \mathrm{O}, \mathrm{F}, \mathrm{Cl}, \mathrm{S}$ and $\mathrm{Br}$ atoms. Since the I atom is not included in the standard $6-31 \mathrm{G}^{* *}$ basis set, it was described by the LANL2DZdp basis, which includes a relativistic ECP and polarization $(d)$ and diffuse $(p)$ functions. ${ }^{33}$ This basis has the efficiency of a core-potential-containing basis set and is believed to provide the accuracy of an all-electron basis set such as $6-31 \mathrm{G}^{* *}$. The $\mathrm{R}$ and $\mathrm{X}$ radicals were optimized with the spin unrestricted formalism; the spin contamination was found to be negligible in all cases (the mean value of the $S^{2}$ operator was always very close to the theoretical value of 0.75 ). All geometry optimizations were performed without symmetry constraints $\left(\mathrm{C}_{1}\right.$ symmetry $)$. The nature of the resulting stationary points as energy minima was verified by a frequency analysis in each case. All energies were corrected for zero point vibrational energy and for thermal energy to obtain the bond dissociation enthalpies at $298 \mathrm{~K}$. A spin-orbit correction was also applied for $\mathrm{X}=$ $\mathrm{Cl}, \mathrm{Br}$ and $\mathrm{I}$ as described in our previous contribution. ${ }^{23} \mathrm{~A}$ further entropy correction was applied to obtain the Gibbs Free Energy at 298 K. The calculations used the standard approximations for estimating of the thermochemical corrections (ideal gas, rigid rotor 
and harmonic oscillator). The atomic charges were calculated using the Natural Population Analysis (NPA). ${ }^{34}$

\section{Results}

The systems chosen for more detailed investigation are the dithioacetate $\mathrm{CH}_{3} \mathrm{C}(\mathrm{S})(\mathrm{SR})$, where $\mathrm{R}$ covers the entire range of radicals previously investigated by us to estimate the BDE of R-X $\left(\mathrm{X}=\mathrm{Cl}, \mathrm{Br}, \mathrm{I}, \mathrm{N}_{3}, \mathrm{~S}_{2} \mathrm{CNMe}_{2}\right)$, plus the 1,1-dichloroethyl $(v d c l)$ radical. They are shown, together with their abbreviation, in Scheme 2. In addition, a selected list of dithiobenzoates, $\mathrm{C}_{6} \mathrm{H}_{5} \mathrm{C}(\mathrm{S})(\mathrm{SR})$, was also calculated.

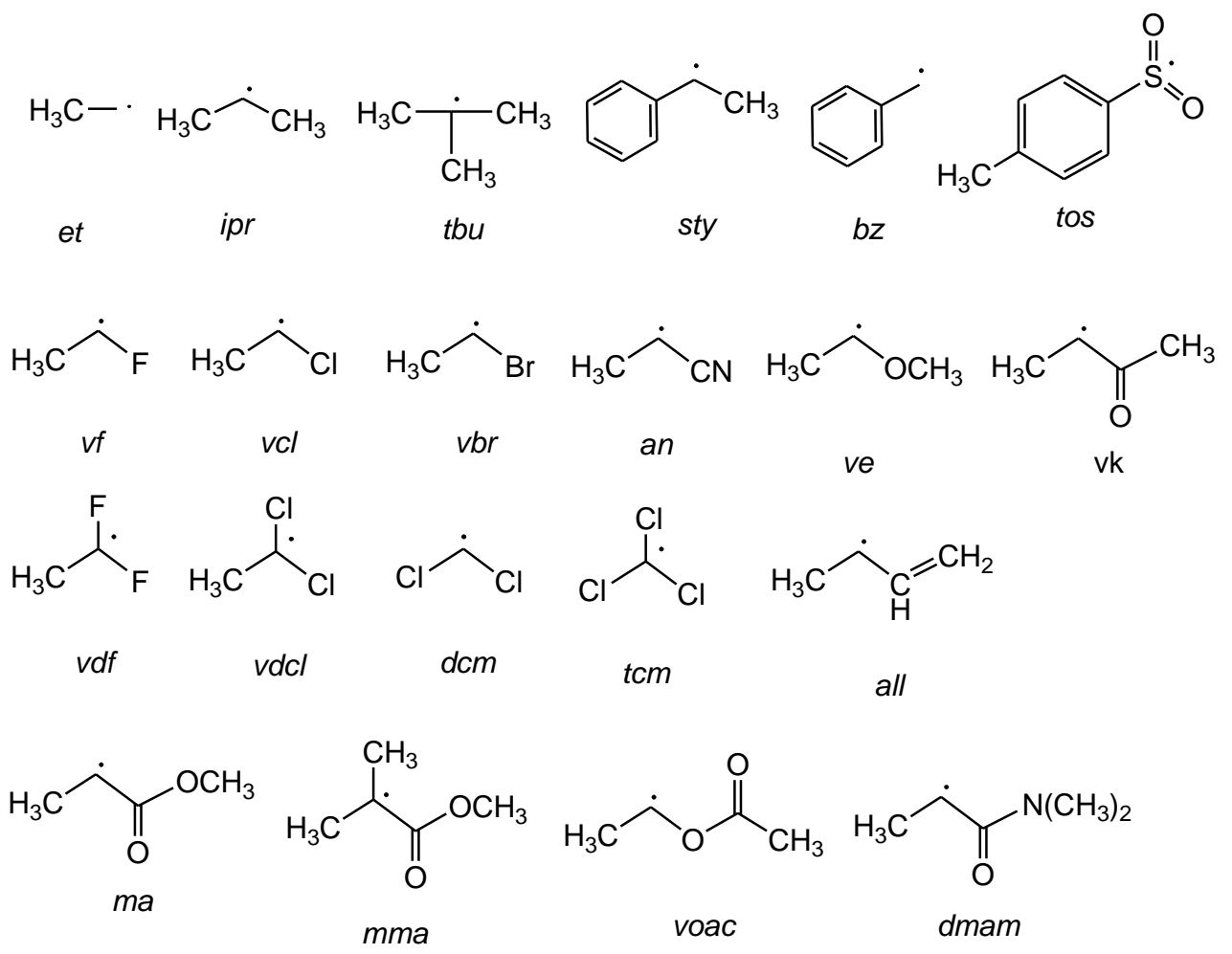

Scheme 2 
The calculations were carried out at the same computational level, as previously used to obtain the energies and thermochemical data for the $\mathrm{R}$ radicals and for the other R-X molecules, ${ }^{23}$ namely using DFT with the BP86 functional and basis sets at the 6$31 \mathrm{G}^{* *}$ level for all atoms. The new data presented in this contribution cannot be directly compared with experimental thermochemical data since these do not appear to be available, but we have shown earlier that this computational level provides BDEs in quite good agreement with the experiment for $\mathrm{R}-\mathrm{X}(\mathrm{X}=\mathrm{Cl}, \mathrm{Br}, \mathrm{I})$ compounds. In combination with the previous calculations for the free radicals, the new results provide BDE's for the $\mathrm{R}-\mathrm{SC}(\mathrm{S}) \mathrm{Z}(\mathrm{Z}=\mathrm{Me}, \mathrm{Ph})$ bonds, Scheme 3, as well as thermochemical and equilibrium data for the exchange reactions shown in Scheme 4. As a comparison standard for the exchange process of Scheme 4, we choose $\mathrm{R}^{1}=$ ma.

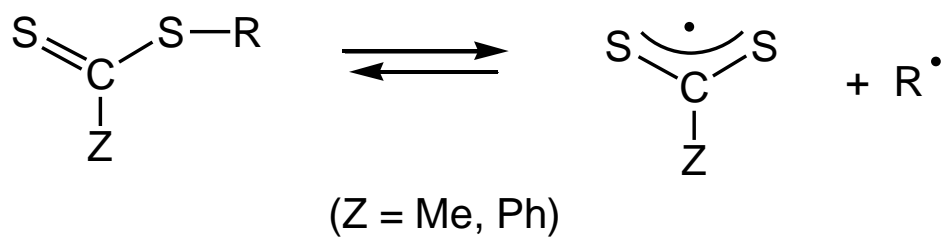

Scheme 3
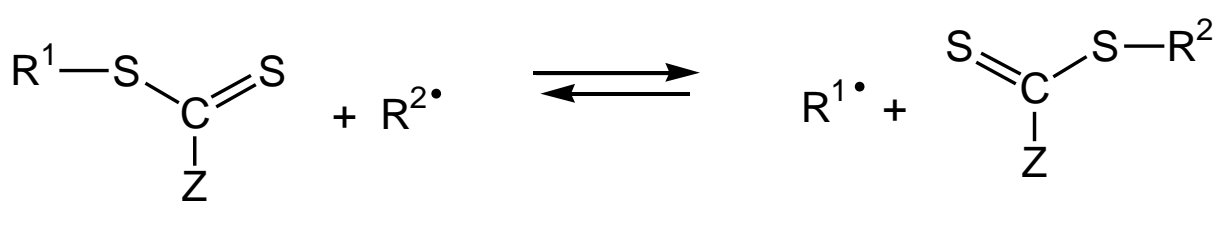

Scheme 4

Geometry and Conformation 
The starting geometry for the simplest molecules was constructed in a straightforward manner. More complex molecules, such as $d \operatorname{mam} \mathrm{S}_{2} \mathrm{CMe}$ for instance, present a conformational problem. We used knowledge from our previous study ${ }^{23}$ in order to obtain the most stable conformation in those cases. In particular, we found that there is an energetic preference for the carboxylate unit $\mathrm{C}^{1}-\mathrm{C}(\mathrm{O})-\mathrm{O}-\mathrm{C}^{2}$ to adopt a planar configuration with a zero dihedral angle (i.e. $\mathrm{C}^{2}$ is located syn to the carbonyl oxygen atom rather than anti). Relative to the simpler $\mathrm{R}-\mathrm{X}$ molecules where $\mathrm{X}=$ halogen (single atom), two new conformational degrees of freedom are introduced for most $\mathrm{R}$ radicals by the dithioacetate unit, namely the two dihedral angles Z-C(S)-S-R and C(S)-S-C-X (Z = $\mathrm{CH}_{3}$ or $\mathrm{C}_{6} \mathrm{H}_{5} ; \mathrm{X}=$ any pivot substituent, e.g. the $\mathrm{Ph}$ group for $b z$ and $s t y$, or the Me group for $v f, v c l, v b r$, an, etc.). By running a few comparison calculations, the first dihedral angle was found to favor the disposition of the $\mathrm{R}$ group syn with respect to the thiocarbonyl sulfur atom, just like for the normal carboxylic unit (the energy difference is systematically in the $4-5 \mathrm{kcal} \mathrm{mol}^{-1}$ range). These conformations correspond to those reported by Coote for the $\mathrm{CH}_{3} \mathrm{SC}(\mathrm{S}) \mathrm{Z}$ compounds with $\mathrm{Z}=\mathrm{CH}_{3}, \mathrm{Ph}$, and $\mathrm{CH}_{2} \mathrm{Ph}^{25}$ The only one exception to this rule is the tos group, which leads to a lower energy geometry (by $4.2 \mathrm{kcal} \mathrm{mol}^{-1}$ ) when located in the anti position. The $\mathrm{C}(\mathrm{S})-\mathrm{S}-\mathrm{C}-\mathrm{X}$ dihedral angle is found to favor conformations having the smaller X substituents closer to the thiocarbonyl group, although the energy difference in this case is smaller (e.g. $0.28 \mathrm{kcal} \mathrm{mol}^{-1}$ for $v f \mathrm{~S}_{2} \mathrm{CMe}$ and $0.78 \mathrm{kcal} \mathrm{mol}^{-1}$ for $m a \mathrm{~S}_{2} \mathrm{CMe}$ ). Comparative views of all optimized dithioacetates are shown in Figure 1, part (a).

The starting geometry for the dithiobenzoates was constructed from the corresponding optimized dithioacetate. The optimized geometries of these systems are 
shown in Figure 1, part (b). The same essential conformational features of the related dithioacetate systems are found for this series. The dithiobenzoate phenyl ring prefers a slightly tilted conformation relative to the $\mathrm{C}-\mathrm{C}(\mathrm{S})-\mathrm{S}$ plane (ca. $30^{\circ}$ ), presumably because of a van der Waals interaction between the ring $o-\mathrm{H}$ atoms and the two $\mathrm{S}$ atoms.

(a) Dithioacetates

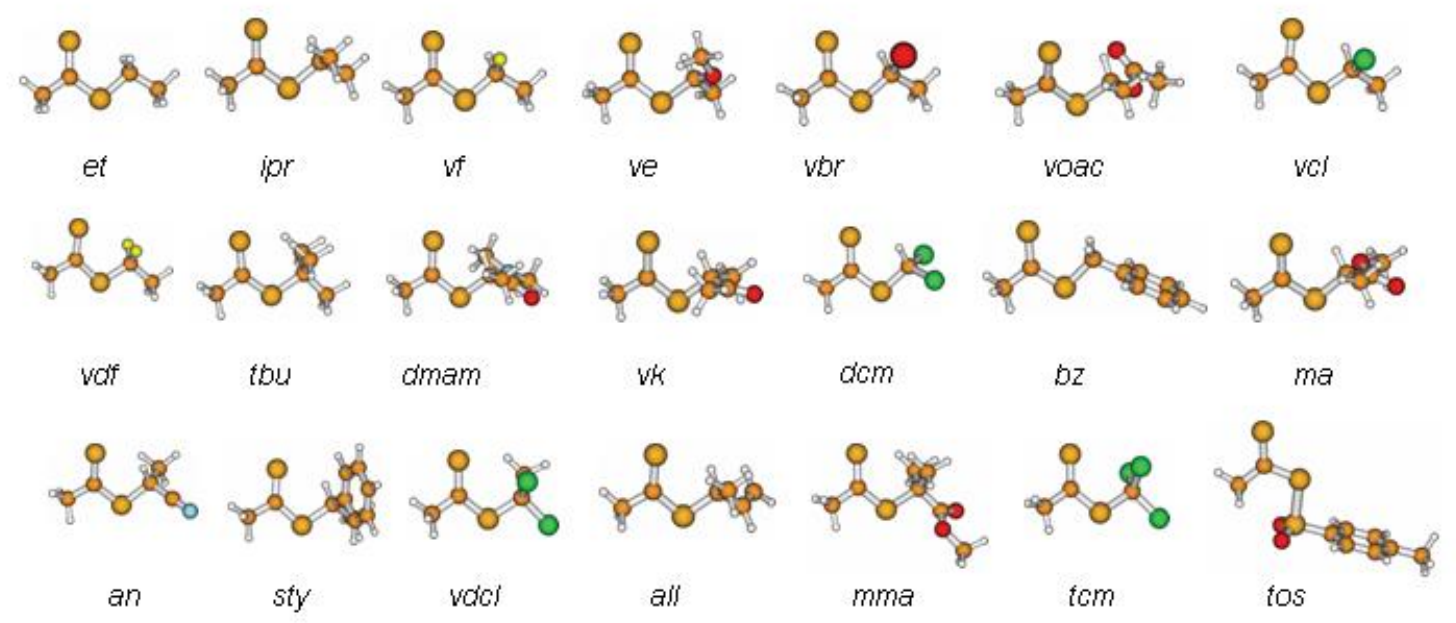

(b) Dithiobenzoates

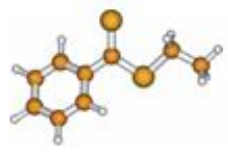

et

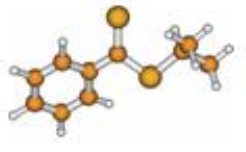

ipr

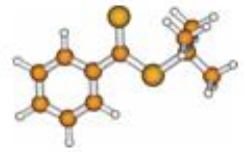

tbu

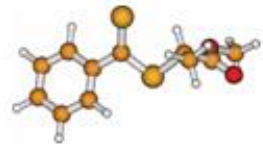

ma

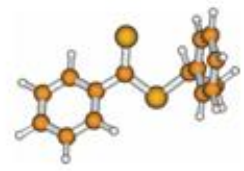

sty

Figure 1. Views of the optimized geometries for all R-SC(S)Z ( $Z=M e, P h)$ molecules.

\section{Thermochemistry}

The computed thermochemical data for the homolytic rupture of the $\mathrm{R}-\mathrm{S}_{2} \mathrm{CZ}$ bonds are presented in Table 1. The values are shown in a decreasing order of bond dissociation enthalpy, i.e. BDE at $298 \mathrm{~K}$, for the dithioacetate series. The BDEs show the same general trend previously reported for the other R-X series, the simple alkyl and 
halogenated alkyl radicals giving the stronger bonds and the more stabilized radicals (sty, all, mma, etc.) the weaker bonds. Comparing the current results with those obtained for the other R-X series, we observe that a given $\mathrm{R}$ forms a stronger bond in the order $\mathrm{I}<$ $\mathrm{S}_{2} \mathrm{CNMe}_{2}<\mathrm{S}_{2} \mathrm{CPh}<\mathrm{S}_{2} \mathrm{CMe}<\mathrm{N}_{3}<\mathrm{Br}<\mathrm{Cl}$, as can be visually appreciated from Figure 2. It can be noted, however, that there are many inversions of relative BDE ordering when going from the dithioacetate series to the $\mathrm{Br}$ and $\mathrm{Cl}$ series. For instance, $v d f$ gives a much stronger bond than $v c l$ with $\mathrm{Cl}$ and $\mathrm{Br}$, whereas it forms a slightly weaker bond with $\mathrm{S}_{2} \mathrm{CMe}$. Another interesting case is an, which forms a weaker bond with $\mathrm{Cl}$ and $\mathrm{Br}$ relative to sty and $v d c l$, whereas the reverse is true for the bond with dithioacetate.

Table 1. Calculated $\Delta \mathrm{H}^{0}, \Delta \mathrm{S}^{0}$ and $\Delta \mathrm{G}^{0}$ for the $\mathrm{R}-\mathrm{S}_{2} \mathrm{CZ}$ bond breaking process at $298 \mathrm{~K}$. $^{\mathrm{a}}$

\begin{tabular}{|c|c|c|c|c|}
\hline $\mathrm{R}$ & $\mathrm{Z}$ & $\begin{array}{c}\Delta \mathrm{H}^{0}{ }_{298} / \\
\mathrm{kcal} \mathrm{mol}^{-1}\end{array}$ & $\begin{array}{c}\Delta S^{0}{ }_{298} / \\
\mathrm{cal} \mathrm{K}^{-1} \mathrm{~mol}^{-1}\end{array}$ & $\begin{array}{c}\Delta \mathrm{G}^{0}{ }_{298} / \\
\mathrm{kcal} \mathrm{mol}^{-1}\end{array}$ \\
\hline \multirow{2}{*}{ et } & $\mathrm{Me}$ & 62.69 & 49.98 & 47.78 \\
\hline & $\mathrm{Ph}$ & 60.21 & 46.65 & 46.30 \\
\hline \multirow[b]{2}{*}{$i p r$} & $\mathrm{Me}$ & 59.44 & 49.68 & 44.63 \\
\hline & $\mathrm{Ph}$ & 57.19 & 50.20 & 42.23 \\
\hline$\overline{v f}$ & $\mathrm{Me}$ & 58.76 & 46.15 & 45.00 \\
\hline ve & $\mathrm{Me}$ & 57.53 & 51.07 & 42.31 \\
\hline$v b r$ & $\mathrm{Me}$ & 57.10 & 47.73 & 42.87 \\
\hline voac & $\mathrm{Me}$ & 55.69 & 47.53 & 41.52 \\
\hline$v c l$ & $\mathrm{Me}$ & 54.84 & 47.72 & 40.61 \\
\hline$v d f$ & $\mathrm{Me}$ & 54.03 & 51.14 & 38.79 \\
\hline \multirow{2}{*}{$t b u$} & $\mathrm{Me}$ & 53.88 & 57.00 & 36.89 \\
\hline & $\mathrm{Ph}$ & 50.47 & 57.76 & 33.25 \\
\hline dmam & $\mathrm{Me}$ & 52.40 & 49.00 & 37.79 \\
\hline$\overline{v k}$ & $\mathrm{Me}$ & 51.24 & 51.10 & 36.00 \\
\hline$d \mathrm{~cm}$ & $\mathrm{Me}$ & 50.25 & 45.58 & 36.66 \\
\hline$\overline{b z}$ & $\mathrm{Me}$ & 49.80 & 40.83 & 37.63 \\
\hline \multirow{2}{*}{$m a$} & $\mathrm{Me}$ & 49.55 & 42.42 & 36.90 \\
\hline & $\mathrm{Ph}$ & 47.37 & 43.71 & 34.34 \\
\hline$a n$ & $\mathrm{Me}$ & 46.58 & 46.87 & 32.61 \\
\hline \multirow{2}{*}{ sty } & $\mathrm{Me}$ & 46.37 & 46.30 & 32.57 \\
\hline & $\mathrm{Ph}$ & 44.28 & 46.25 & 30.49 \\
\hline$\overline{v d c l}$ & $\mathrm{Me}$ & 44.29 & 49.50 & 29.53 \\
\hline all & $\mathrm{Me}$ & 43.29 & 49.69 & 28.48 \\
\hline
\end{tabular}




\begin{tabular}{lllll}
\hline$m m a$ & $\mathrm{Me}$ & 41.07 & 50.30 & 26.07 \\
\hline tcm & $\mathrm{Me}$ & 39.57 & 52.32 & 23.97 \\
\hline tos & $\mathrm{Me}$ & 29.67 & 46.81 & 15.71 \\
\hline
\end{tabular}

a The necessary thermochemical parameters for the free $\mathrm{R}$ radicals were taken from the previous study. ${ }^{23}$

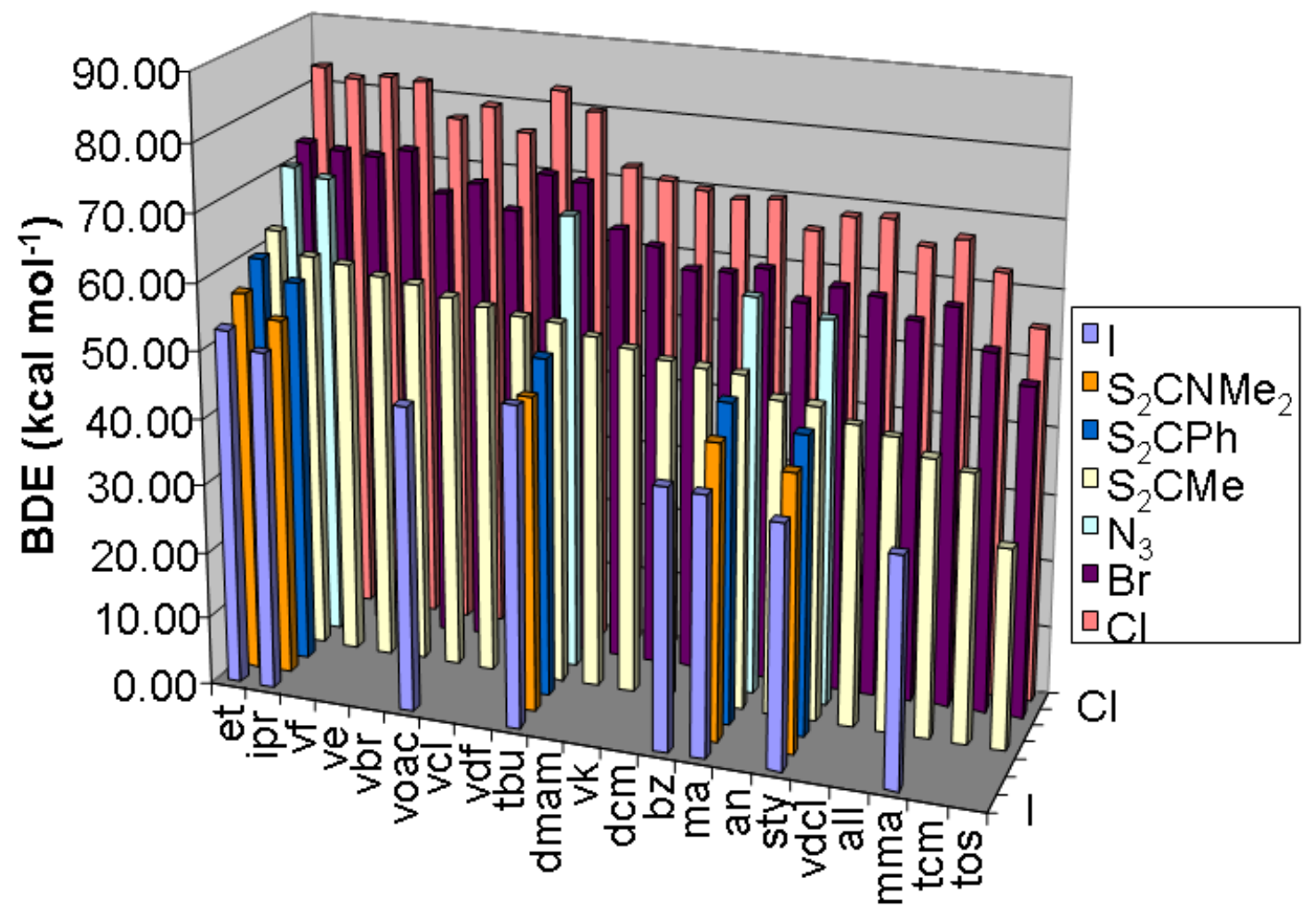

Figure 2. Graphical representation of the R-X BDEs $\left(\Delta \mathrm{H}^{\circ}{ }_{298}\right)$ as a function of $\mathrm{R}$ and $\mathrm{X}$. The chosen order of $\mathrm{R}$ is that giving a monotonous decreasing BDE order for the dithioacetate series.

This variation in relative bond energy ordering can be even better appreciated by comparing the exchange free energies, $\Delta \Delta \mathrm{G}^{\circ}$ [expressed relative to the standard $m a$ radical: $\left.\Delta \Delta \mathrm{G}^{\circ}(\mathrm{R})=\Delta \mathrm{G}^{\circ}(m a)-\Delta \mathrm{G}^{\circ}(\mathrm{R})\right]$ for the dithioacetate series (Scheme 4), with the corresponding values obtained from the BDE's of other R-X systems. These data are explicitly shown in Table 2. The trends shown by the $\mathrm{Cl}$ and $\mathrm{Br}$ series agree quite well 
with each other but are rather different than those of the dithioacetate and dithiobenzoate series. The latter ones agree better with the few examples calculated for the dithiocarbamate series ( $c f$. for instance the values of $t b u$ ).

Table 2. Calculated $\Delta \Delta \mathrm{G}^{\circ}$ values at $298 \mathrm{~K}$ for the exchange reaction $m a-\mathrm{X}+\mathrm{R}^{\bullet}$

\begin{tabular}{|c|c|c|c|c|c|c|c|}
\hline \multirow[t]{2}{*}{$\mathrm{R}$} & \multicolumn{7}{|c|}{$X$} \\
\hline & $\mathrm{I}$ & $\mathrm{S}_{2} \mathrm{CNMe}_{2}$ & $\mathrm{~S}_{2} \mathrm{CPh}$ & $\mathrm{S}_{2} \mathrm{CMe}$ & $\mathrm{N}_{3}$ & $\mathrm{Br}$ & $\mathrm{Cl}$ \\
\hline et & -14.28 & -12.50 & -11.97 & -10.88 & -11.77 & -11.38 & -12.66 \\
\hline$i p r$ & -10.84 & -7.17 & -7.89 & -7.72 & -9.71 & -9.85 & -10.73 \\
\hline$v f$ & & & & -8.10 & & -10.28 & -12.20 \\
\hline ve & & & & -5.41 & & -11.35 & -11.65 \\
\hline$v b r$ & & & & -5.97 & & -5.61 & -6.63 \\
\hline voac & -6.32 & & & -4.62 & & -7.68 & -8.99 \\
\hline$v c l$ & & & & -3.71 & & -4.08 & -5.45 \\
\hline$v d f$ & & & & -1.89 & & -10.09 & -12.42 \\
\hline$t b u$ & -7.39 & -0.94 & 1.08 & 0.01 & -7.36 & -8.25 & -8.52 \\
\hline dmam & & & & -0.89 & & -2.31 & -1.73 \\
\hline$v k$ & & & & 0.90 & & -1.49 & -0.91 \\
\hline$d c m$ & & & & 0.24 & & 1.36 & 0.53 \\
\hline$b z$ & -1.24 & & & -0.73 & & -0.39 & -0.42 \\
\hline$m a$ & 0.00 & 0.00 & 0.00 & 0.00 & 0.00 & 0.00 & 0.00 \\
\hline an & & & & 4.30 & & 4.65 & 4.61 \\
\hline sty & 2.62 & 2.85 & 3.84 & 4.33 & 2.00 & 1.58 & 1.65 \\
\hline$v d c l$ & & & & 7.37 & & 2.83 & 1.82 \\
\hline all & & & & 8.42 & & 4.92 & 4.59 \\
\hline$m m a$ & 4.57 & & & 10.83 & & 2.41 & 3.01 \\
\hline $\mathrm{tcm}$ & & & & 12.93 & & 8.57 & 8.29 \\
\hline tos & & & & 21.19 & & 12.23 & 14.75 \\
\hline
\end{tabular}

${ }^{a}$ Values are given in $\mathrm{kcal} \mathrm{mol}^{-1}$. The values relative to $\mathrm{X}=\mathrm{Cl}, \mathrm{Br}, \mathrm{I}, \mathrm{N}_{3}$ and $\mathrm{S}_{2} \mathrm{CNMe}_{2}$ were calculated from previously published data. ${ }^{23}$

The different value of $\Delta \Delta \mathrm{G}^{\circ}$ for some of the systems can be clearly attributed to steric effects. For a larger $\mathrm{X}$ group, a larger $\mathrm{R}$ (relative to the standard $m a$ ) will tend to give less negative (or more positive) enthalpy values for the exchange process. This explains rather well the $t b u$ trend. Note that the effect is shown also within the halide 
series, but becomes particularly important on going to the more sterically demanding dithioacetate and especially dithiobenzoate and dithiocarbamate. A similar trend is shown by mma. Smaller R groups (relative to $m a$ ) show the opposite trend (e.g. see the et series on going from $\mathrm{Cl}$ to I). However, an electronic effect superimposes with the steric effect. This is most clearly shown by the large differences observed for the R groups that bear strongly electronegative substituents on the $\alpha-C$ atom. The $\Delta \Delta \mathrm{G}^{\circ}$ value is less

negative for the $\mathrm{S}_{2} \mathrm{CMe}$ system relative to the $\mathrm{Cl}$ system by $4.1 \mathrm{kcal} \mathrm{mol}^{-1}$ for $v f$ (one $\mathrm{F}$ atom), by $6.25 \mathrm{kcal} \mathrm{mol}^{-1}$ for ve (one OMe group), by $4.37 \mathrm{kcal} \mathrm{mol}^{-1}$ for voac (one OAc group), and by $10.53 \mathrm{kcal} \mathrm{mol}^{-1}$ for $v d f$ (two $\mathrm{F}$ atoms). The effect is much smaller but still noticeable for the $\mathrm{Cl}$ substituents, i.e. $\Delta \Delta \mathrm{G}^{0}$ is essentially the same for the $\mathrm{Cl}$ and $\mathrm{S}_{2} \mathrm{CMe}$ derivatives of $d c m$, whereas it goes from $8.29 \mathrm{kcal} \mathrm{mol}^{-1}(\mathrm{Cl})$ to $12.93\left(\mathrm{~S}_{2} \mathrm{CMe}\right)$ for $t c m$, which contains thee $\alpha-\mathrm{Cl}$ atoms.

\section{Electronic effects}

The electronic effect may be correlated to the ionic contribution to the bond strength. An increase in bond polarity for the R-X bond signifies that some extra energy must be paid to redistribute the charge during the formation of the neutral radical species. Therefore, it is logical to expect that an electronegative substituent on the $\alpha-\mathrm{C}$ atom renders this atom less negatively (or more positively) charged, thereby decreasing the Coulombic repulsion (or increasing the attraction) with a negatively charged $\mathrm{X}$ group. Obviously, the effect is expected to be greater in the order $\mathrm{Cl}>\mathrm{Br}>\mathrm{I}$ and even smaller for the sulfur based $\mathrm{X}$ groups. In order to test this idea, we have calculated the natural charge $^{34}$ on the $\mathrm{C}$ atom and on the $\mathrm{X}$ group. The results, collected in Table 3, confirm the 
validity of our hypothesis. To facilitate reading, the table is organized in a different way than the previous ones: the $\mathrm{R}$ groups are listed in order of decreasing natural charge for the reference chloride series, whereas the $\mathrm{X}$ groups are listed in order of increasing natural charge.

The trends to be noted are as follows: $(i)$ the $\mathrm{q}(\mathrm{C})$ charges in the chloride series display the same trend as in the bromide series, which is generally followed also for the dithioacetate series. (ii) $\mathrm{q}(\mathrm{C})$ values are slightly negative for those $\mathrm{R}$ groups that do not bear $\mathrm{O}$ or $\mathrm{F}$ substituents on the $\alpha-\mathrm{C}$ atom (e.g. in the -0.45 to 0 range for the chloride series). The introduction of $\mathrm{O}$ or $\mathrm{F}$ substituents increases substantially this charge. The effect is particularly dramatic for $v d f$, having two F substituents on the $\alpha-\mathrm{C}$ atom. These trends parallel quite well the discrepancies noted above in Table 2. (iii) Somewhat unexpectedly, the introduction of $\mathrm{Br}$ (in $v b r$ ) or $\mathrm{Cl}$ (in $v c l$, $v d c l$ or tcm) does not give particularly higher charges for the $\alpha$-C atom, compared with other groups that do not bear heteroatom substituents. Again, this phenomenon parallels the lack of a particular discrepancy in $\Delta \Delta \mathrm{G}^{\circ}$ for those $\mathrm{R}$ groups when going from the $\mathrm{Cl}$ and $\mathrm{Br}$ series to the dithioacetate series. Thus, an important effect related to the electronegativity difference [both in the $\mathrm{q}(\mathrm{C})$ of the $\alpha-\mathrm{C}$ atom and in the $\Delta \Delta \mathrm{G}^{\circ}$ ] seems limited to $\mathrm{O}$ and $\mathrm{F}$ substituents. (iv) the $\mathrm{q}(\mathrm{C})$ charge for a given $\mathrm{R}$ group becomes quite expectedly more negative (or less positive) as $\mathrm{q}(\mathrm{X})$ becomes less negative. ( $(v) \mathrm{q}(\mathrm{X})$ increases as expected on going from $\mathrm{Cl}$ to $\mathrm{Br}$ to I; also in line with expectations, it increases, though by a lesser extent, on going from $\mathrm{S}_{2} \mathrm{CNEt}_{2}$ to $\mathrm{S}_{2} \mathrm{CPh}$ and further to $\mathrm{S}_{2} \mathrm{CMe}$; it is in general about the same for I and $\mathrm{S}_{2} \mathrm{CMe}$ (slighly more positive with the former for some $\mathrm{R}$ groups, with the latter for others). It is necessary to point out that the ionic component of the R-X bond is affected 
by the resonance contribution of the charge-separated form (see Scheme 5) when $X=$ $\mathrm{S}_{2} \mathrm{CMe}, \mathrm{S}_{2} \mathrm{CPh}$ or $\mathrm{S}_{2} \mathrm{CNMe}_{2}{ }^{35}(v i) \mathrm{q}(\mathrm{X})$ is quite negative for the azide compounds. This allows us to predict that an anomaly for $\mathrm{O}$ and $\mathrm{F}$-substituted $\mathrm{R}$ groups will also occur for the $\mathrm{N}_{3}$ series, but this time in the opposite direction, namely $\Delta \Delta \mathrm{G}^{\circ}$ in Table 2 should be more negative for azide compounds relative to the $\mathrm{Cl}$ and $\mathrm{Br}$ series.<smiles>[R]SC([Z])[Hg]CCC</smiles>

\section{Scheme 5}

Similar effects were recently reported for high level ab initio molecular orbital calculations for $\mathrm{R}=\mathrm{Me}, \mathrm{Et}, i \mathrm{Pr}$ and $t \mathrm{Bu}$ and leaving groups with various electronegativity (F, OH, OMe, Me, and $\mathrm{H})$. BDEs depend strongly on the nature of $\mathrm{X}$ and inverse stability orders have been reported and explained by the importance of stabilization of $\mathrm{R}-\mathrm{X}$ bond by the $\mathrm{R}^{+} \mathrm{X}^{-}$ionic configuration. ${ }^{36}$ 
Table 3. Natural charge on the $\mathrm{C}$ atom and $\mathrm{X}$ group for all $\mathrm{R}-\mathrm{X}$ molecules.

\begin{tabular}{|c|c|c|c|c|c|c|c|c|c|c|c|c|c|c|}
\hline & \multicolumn{2}{|c|}{$\mathrm{N}_{3}$} & \multicolumn{2}{|c|}{$\mathrm{Cl}$} & \multicolumn{2}{|c|}{$\mathrm{Br}$} & \multicolumn{2}{|c|}{$\mathrm{S}_{2} \mathrm{CNMe}_{2}$} & \multicolumn{2}{|c|}{$\mathrm{S}_{2} \mathrm{CPh}$} & \multicolumn{2}{|c|}{$\mathrm{S}_{2} \mathrm{CMe}$} & \multicolumn{2}{|c|}{ I } \\
\hline & $q(C)$ & $q(X)$ & $q(C)$ & $q(X)$ & $q(C)$ & $q(X)$ & $q(C)$ & $q(X)$ & $q(C)$ & $q(X)$ & $\mathrm{q}(\mathrm{C})$ & $q(X)$ & $q(C)$ & $q(X)$ \\
\hline$b z$ & & & -0.458 & -0.087 & -0.520 & -0.039 & & & & & -0.634 & 0.062 & -0.627 & 0.048 \\
\hline et & -0.306 & -0.207 & -0.456 & -0.091 & -0.520 & -0.041 & -0.624 & 0.044 & -0.630 & 0.047 & -0.630 & 0.048 & -0.638 & 0.058 \\
\hline$d c m$ & & & -0.377 & 0.028 & -0.451 & 0.083 & & & & & -0.512 & 0.167 & & \\
\hline$v b r$ & & & -0.340 & -0.020 & -0.410 & 0.032 & & & & & -0.495 & 0.136 & & \\
\hline$a n$ & & & -0.345 & -0.027 & -0.406 & 0.030 & & & & & -0.513 & 0.134 & & \\
\hline$m a$ & -0.191 & -0.172 & -0.327 & -0.054 & -0.386 & 0.002 & -0.501 & 0.091 & -0.503 & 0.102 & -0.507 & 0.105 & -0.501 & 0.108 \\
\hline$v k$ & & & -0.323 & -0.074 & -0.374 & -0.012 & & & & & -0.503 & 0.098 & & \\
\hline dmam & & & -0.313 & -0.073 & -0.367 & -0.018 & & & & & -0.488 & 0.091 & & \\
\hline $\mathrm{tcm}$ & & & -0.290 & 0.072 & -0.363 & 0.129 & & & & & -0.387 & 0.189 & & \\
\hline$v c l$ & & & -0.275 & -0.031 & -0.340 & 0.020 & & & & & -0.428 & 0.126 & & \\
\hline all & & & -0.252 & -0.094 & -0.304 & -0.047 & & & & & -0.420 & 0.055 & & \\
\hline sty & -0.100 & -0.196 & -0.234 & -0.092 & -0.289 & -0.043 & -0.393 & 0.052 & -0.405 & 0.063 & -0.407 & 0.065 & -0.381 & 0.032 \\
\hline$i p r$ & -0.094 & -0.212 & -0.230 & -0.101 & -0.286 & -0.054 & -0.396 & 0.048 & -0.400 & 0.046 & -0.402 & 0.049 & -0.390 & 0.041 \\
\hline$v d c l$ & & & -0.152 & 0.025 & -0.219 & 0.078 & & & & & -0.278 & 0.163 & & \\
\hline$m m a$ & & & -0.110 & -0.061 & -0.159 & -0.008 & & & & & -0.264 & 0.080 & -0.255 & 0.088 \\
\hline$t b u$ & 0.109 & -0.215 & -0.016 & -0.103 & -0.063 & -0.060 & -0.154 & 0.036 & -0.161 & 0.036 & -0.169 & 0.047 & -0.154 & 0.028 \\
\hline voac & & & 0.073 & -0.087 & 0.023 & -0.045 & & & & & -0.068 & 0.053 & -0.070 & 0.033 \\
\hline ve & & & 0.113 & -0.157 & 0.075 & -0.134 & & & & & -0.042 & 0.005 & & \\
\hline$v f$ & & & 0.190 & -0.088 & 0.142 & -0.048 & & & & & 0.038 & 0.060 & & \\
\hline$v d f$ & & & 0.744 & -0.065 & 0.702 & -0.027 & & & & & 0.633 & 0.053 & & \\
\hline$t_{o s}^{\mathrm{a}}$ & & & 2.127 & -0.272 & 2.068 & -0.212 & & & & & 2.009 & -0.070 & & \\
\hline
\end{tabular}

${ }^{\mathrm{a}}$ Charge for the $\mathrm{S}$ atom bonded to $\mathrm{X}$. 


\section{Discussion}

The calculated BDE data can be used to estimate the relative values of the equilibrium constants $\left(\mathrm{K}_{1 / 2}\right.$, see Scheme 6$)$ in CRP. They can be used to compare overall polymerization rates in ATRP but also the relative proportion of dormant and active species exchanging during copolymerization in either ATRP or RAFT. A higher $\mathrm{K}_{1 / 2}$ value indicates relatively higher equilibrium constant $K_{1}$ and relatively higher concentration of radicals $\mathrm{P}_{\mathrm{n} 1}$ * Thus, for higher $\mathrm{K}_{1 / 2}$, more radicals $\mathrm{P}_{\mathrm{n} 1}$ * but also more dormant species $\mathrm{P}_{\mathrm{n} 2}-\mathrm{X}$ should be present in comparison with $\mathrm{P}_{\mathrm{n} 2} *$ and $\mathrm{P}_{\mathrm{n} 1}-\mathrm{X}$, see Equation 1. The relative stabilities of dormant vs. active species for two different alkyl groups can be correlated with the ATRP initiation efficiency, with the chain transfer efficiency in RAFT, and also with the cross-propagation efficiency in block copolymerization.

$$
P_{n 2}^{\bullet}+X-P_{n 1} \stackrel{K_{1 / 2}}{\rightleftharpoons} P_{n 2}-X+P_{n 1}^{\bullet}
$$

Scheme 6

\section{Equation 1}

$\left[\mathrm{P}_{\mathrm{n} 2}-\mathrm{X}\right] /\left[\mathrm{P}_{\mathrm{n} 1}-\mathrm{X}\right]=\mathrm{K}_{1 / 2}\left(\left[\mathrm{P}_{\mathrm{n} 2} *\right] /\left[\mathrm{P}_{\mathrm{n} 1} *\right]\right)$

In ATRP, the $\mathrm{K}_{1 / 2}$ equals to the ratio $\left(\mathrm{k}_{\mathrm{a} 1} \cdot \mathrm{k}_{\mathrm{d} 2}\right) /\left(\mathrm{k}_{\mathrm{d} 1} \cdot \mathrm{k}_{\mathrm{a} 2}\right)$, where values of $\mathrm{k}_{\mathrm{a}}$ and $\mathrm{k}_{\mathrm{d}}$ are the activation and deactivation rate constants, see Scheme 7 . In RAFT, $\mathrm{K}_{1 / 2}$ formally equals to the ratio $\left(\mathrm{k}_{\mathrm{a}} \cdot \mathrm{k}_{\beta}\right) /\left(\mathrm{k}_{-\mathrm{a}} \cdot \mathrm{k}_{-}\right)$, where $\mathrm{k}_{\mathrm{a}}$ and $\mathrm{k}_{-}-\beta$ are the rate constants of addition, 
and $\mathrm{k}_{\mathrm{-a}}$ and $\mathrm{k}_{\beta}$ are the rate constants of fragmentation, see Scheme 8. The efficiency of cross-propagation in RAFT depends not only on the ratio of the above rate constants but also on their absolute values as well as the rate constants of propagation, ${ }^{5,37}$ see Equation 2. If fragmentation from the intermediate radical to the initiating/cross-propagating radical $P_{n 1} *$ is slower than to $P_{n 2} *\left(k_{-a}>>k_{\beta}\right)$, then Equation 2 reduces to Equation 3. Thus, the transfer coefficient for RAFT agents (and also for cross-propagation) should increase with the relative values of $\mathrm{K}_{1 / 2}$. It should also depend on the ratio of the re-addition to the cross-propagation rate constant.

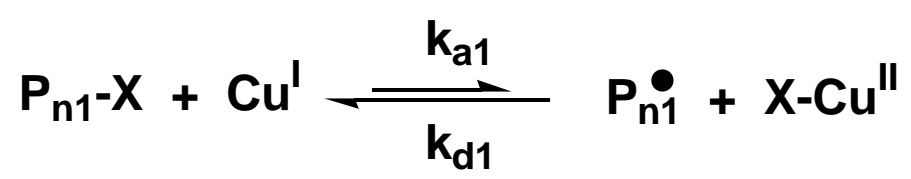

Scheme 7

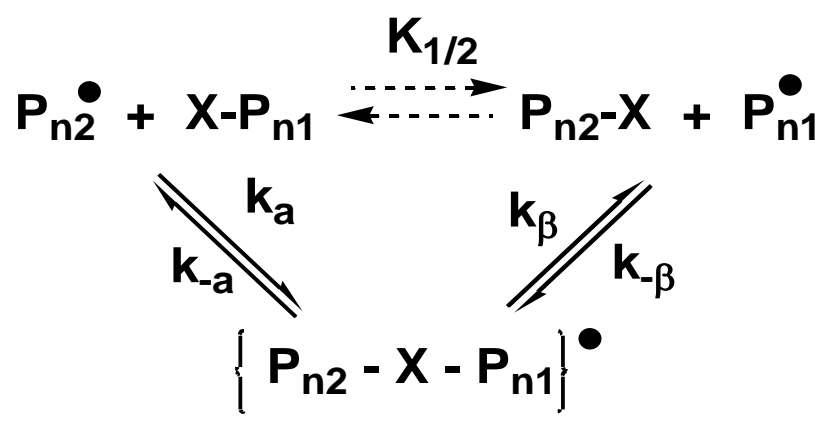

Scheme 8

Equation 2

$C_{t r}=\frac{k_{a} k_{\beta}}{k_{p}\left(k_{-a}+k_{\beta}\right)}$ 


\section{Equation 3}

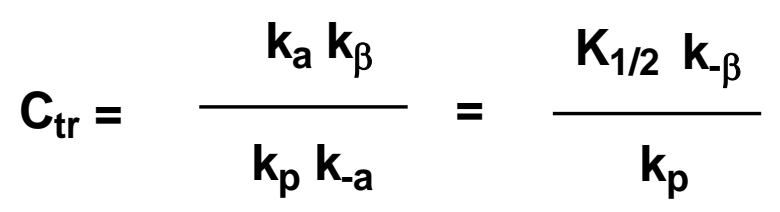

However, it should be noted that the efficiency of RAFT systems depends not only on the overall equilibrium constant $\mathrm{K}_{1 / 2}$ but also on the individual addition and fragmentation rate constants.

\section{Relative values of equilibrium constants}

It is interesting to compare not only the equilibrium constants for the radical exchange involving same leaving group $X$, but also the one associated to the double exchange involving two radicals $\left(\mathrm{R}^{1}\right.$ and $\mathrm{R}^{2}$ ) and two substituents ( $\mathrm{X}$ and $\left.\mathrm{Y}\right)$, see Scheme 9. This could aid in a better selection of macroinitiators for block copolymerization and also select better CRP technique for the particular monomers which should be block copolymerized. In ATRP, it is possible to additionally apply halogen exchange to switch successfully from less reactive to more reactive monomers, i.e., polyacrylates to polymethacrylates. $^{38-41}$

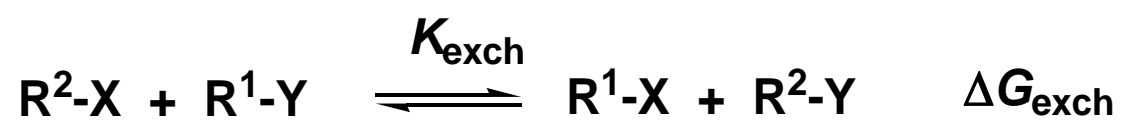

Scheme 9

Table 4 presents the computed free energy values for the double exchange of Scheme 9 using methyl 2-X-propionate and $\mathrm{Cl}$ as standards for $\mathrm{R}$ and $\mathrm{X}$. The reported 
values are calculated as $\Delta \mathrm{G}_{\mathrm{exch}}\left(\mathrm{R}^{1} \mathrm{X}\right)=\Delta \Delta \mathrm{G}^{\mathrm{X}}\left(\mathrm{R}^{1}\right)-\Delta \Delta \mathrm{G}^{\mathrm{Cl}}\left(\mathrm{R}^{1}\right)$, using the $\Delta \Delta \mathrm{G}$ values of Table 2. The $\Delta \mathrm{G}_{\text {exch }}\left(\mathrm{R}^{1} \mathrm{X}\right)$ values are relatively small for any $\mathrm{R}^{1}$ when $\mathrm{X}=\mathrm{Br}, \mathrm{I}$ and $\mathrm{N}_{3}$, within the experimental accuracy of DFT $(\sim 2 \mathrm{kcal} / \mathrm{mol})$. Slightly larger values were obtained only for vdf-Br $\left(\mathrm{MeCF}_{2}-\mathrm{Br}\right)$, tos- $\mathrm{Br} \quad\left(\mathrm{Me}-\mathrm{PhSO}_{2}-\mathrm{Br}\right)$ and voac-I $(\mathrm{MeC}(\mathrm{O}) \mathrm{OCH}(\mathrm{Me})-\mathrm{I})$.

Table 4. $\Delta \mathrm{G}_{\text {exch }}$ for the double exchange of Scheme 9, normalized to $\mathrm{R}^{2}-\mathrm{Y}=$ methyl 2Cl-propionate.

\begin{tabular}{|c|c|c|c|c|c|c|c|}
\hline \multirow{2}{*}{$\mathbf{R}^{1}$} & \multicolumn{7}{|c|}{$x$} \\
\hline & I & $\mathrm{S}_{2} \mathrm{CNMe}_{2}$ & $\mathrm{~S}_{2} \mathrm{CPh}$ & $\mathrm{S}_{2} \mathrm{CMe}$ & $\mathbf{N}_{3}$ & $\mathrm{Br}$ & $\mathrm{Cl}$ \\
\hline et & -1.63 & 0.16 & 0.69 & 1.78 & 0.88 & 1.28 & 0.00 \\
\hline ipr & -0.11 & 3.56 & 2.84 & 3.01 & 1.03 & 0.88 & 0.00 \\
\hline$v f$ & & & & 4.10 & & 1.91 & 0.00 \\
\hline ve & & & & 6.25 & & 0.31 & 0.00 \\
\hline vynbr & & & & 0.66 & & 1.01 & 0.00 \\
\hline voac & 2.67 & & & 4.37 & & 1.31 & 0.00 \\
\hline vyncl & & & & 1.74 & & 1.37 & 0.00 \\
\hline$v d f$ & & & & 10.54 & & 2.33 & 0.00 \\
\hline$t b u$ & 1.14 & 7.58 & 9.60 & 8.53 & 1.16 & 0.27 & 0.00 \\
\hline dmam & & & & 0.83 & & -0.58 & 0.00 \\
\hline$v k$ & & & & 1.81 & & -0.57 & 0.00 \\
\hline $\mathrm{dcm}$ & & & & -0.30 & & 0.83 & 0.00 \\
\hline$b z$ & -0.83 & & & -0.31 & & 0.03 & 0.00 \\
\hline ma & 0.00 & 0.00 & 0.00 & 0.00 & 0.00 & 0.00 & 0.00 \\
\hline an & & & & -0.31 & & 0.04 & 0.00 \\
\hline sty & 0.97 & 1.20 & 2.19 & 2.68 & 0.35 & -0.08 & 0.00 \\
\hline vdcl & & & & 5.55 & & 1.01 & 0.00 \\
\hline all & & & & 3.83 & & 0.33 & 0.00 \\
\hline mma & 1.57 & & & 7.83 & & -0.60 & 0.00 \\
\hline tcm & & & & 4.63 & & 0.27 & 0.00 \\
\hline tos & & & & 6.44 & & -2.52 & 0.00 \\
\hline
\end{tabular}

However, the $\Delta \mathrm{G}_{\text {exch }}$ values for the dithio compounds are significantly larger for selected $\mathrm{R}^{1}$ radicals. The largest values are noted for the disubstituted radicals for which $\mathrm{K}_{\text {exch }}$ is sometimes lower than $10^{-6},\left[\Delta \mathrm{G}_{\text {exch }}>10 \mathrm{kcal} / \mathrm{mol}(v d f), \sim 9 \mathrm{kcal} / \mathrm{mol}(t b u), \sim 8\right.$ $\mathrm{kcal} / \mathrm{mol}(\mathrm{mma})$ and $>6 \mathrm{kcal} / \mathrm{mol}($ tos $)]$. It seems that dithioesters and dithiocarbamates 
of sterically crowded $\mathrm{R}$ groups (e.g. tbu, mma), or groups that are bear very electron withdrawing substituents in the $\alpha$ position (e.g. $v d f$, vf, ve, voac) transfer the $\mathrm{R}$ group to $\mathrm{Cl}$ more easily.

These data are in agreement with experimental results. $t \mathrm{Bu}$ halides are very inefficient ATRP initiators for polymerization of acrylates and other monomers which, on the other hand, are polymerized successfully by ATRP $\left(\Delta \Delta \mathrm{G}^{\circ} \sim-8 \mathrm{kcal} / \mathrm{mol}\right) .{ }^{42,43}$ However, $t \mathrm{Bu}$ dithioesters perform much better in RAFT $\left.\Delta \Delta \mathrm{G}^{\circ} \sim 1 \mathrm{kcal} / \mathrm{mol}\right)$. The relative equilibrium constant is $\sim 10^{6}$ times more favorable $\left(\Delta \mathrm{G}_{\text {exch }}=9.60\right.$ and 8.53 $\mathrm{kcal} / \mathrm{mol}$ for dithiobenzoate and dithioacetate, respectively) than in ATRP. The relative values of transfer coefficient in RAFT of MMA for various R groups is $m m a>s t y>b z \sim$ $t b u .^{30,44}$ This order qualitatively agrees with the order deduced from Table 2 and Table 4.

\section{Relative concentrations of dormant species}

The $\mathrm{K}_{1 / 2}$ values can also be used to predict relative dormant species concentrations in various statistical copolymerizations. In the fully equilibrated system, the relative proportion of growing radicals is defined by comonomer concentrations and crosspropagation rate constants, which can be estimated from the reactivity ratios and homopropagation rate constants (available, for instance, from pulse laser polymerization experiments), see Equation 4. Combination of this equation with Equation 1 leads to Equation 5. Thus, a higher concentration of dormant species $\left[\mathrm{P}_{\mathrm{n} 2}-\mathrm{X}\right]$ will be observed for higher $\mathrm{K}_{1 / 2}$, for higher $\left[\mathrm{M}_{2}\right]$, but also for higher $\mathrm{r}_{2}$ and for lower $\mathrm{k}_{22}$, i.e. when the $\mathrm{M}_{2}$ monomer propagates slower but cross-propagates slower still. 


\section{Equation 4}

$$
\left[\mathrm{P}_{\mathrm{n} 2} *\right] /\left[\mathrm{P}_{\mathrm{n} 1} *\right]=\left(\mathrm{k}_{12} \cdot\left[\mathrm{M}_{2}\right]\right) /\left(\mathrm{k}_{21} \cdot\left[\mathrm{M}_{1}\right]\right)=\left(\mathrm{k}_{11} \cdot \mathrm{r}_{2} \cdot\left[\mathrm{M}_{2}\right]\right) /\left(\mathrm{k}_{22} \cdot \mathrm{r}_{1} \cdot\left[\mathrm{M}_{1}\right]\right)
$$

\section{Equation 5}

$\left[\mathrm{P}_{\mathrm{n} 2}-\mathrm{X}\right] /\left[\mathrm{P}_{\mathrm{n} 1}-\mathrm{X}\right]=\mathrm{K}_{1 / 2} \cdot\left(\mathrm{k}_{11} \cdot \mathrm{r}_{2} \cdot\left[\mathrm{M}_{2}\right]\right) /\left(\mathrm{k}_{22} \cdot \mathrm{r}_{1} \cdot\left[\mathrm{M}_{1}\right]\right)$

For example in copolymerization of equimolar amounts of methyl or butyl acrylate with methyl methacrylate at $90 \mathrm{C}\left(\mathrm{k}_{11} \sim 50,000 \mathrm{~mol} \mathrm{l}^{-1} \mathrm{~s}^{-1}, \mathrm{k}_{22} \sim 2,000 \mathrm{~mol} \mathrm{l}^{-1} \mathrm{~s}^{-1}\right.$, $\left.\mathrm{r}_{1} \sim 0.3, \mathrm{r}_{2} \sim 3\right)$, the methacrylate radicals will strongly dominate $(\sim 250: 1)$ but concentration of dormant species will depend very strongly on the capping agent. For dithioacetate systems, acrylate dormant chains would strongly dominate over methacrylate dormant species $\left(10^{6}: 1\right.$ !) although they could be comparable for ATRP (Br, $\mathrm{Cl})$.

In copolymerization of equimolar amounts of methyl or butyl acrylate with styrene $\left(\mathrm{k}_{11} \sim 50,000 \mathrm{~mol} \mathrm{l}^{-1} \mathrm{~s}^{-1}, \mathrm{k}_{22} \sim 1,000 \mathrm{~mol} \mathrm{l}^{-1} \mathrm{~s}^{-1}, \mathrm{r}_{1} \sim 0.2, \mathrm{r}_{2} \sim 0.8\right)$, styryl radicals should dominate (200:1). For RAFT mediated by dithioacetates, the concentration ratio of acrylate dormant species to styrene dormant species should be 8:1, for dithiobenzoates this ratio should be 3:1, but for dithiocarbamate, bromide and chloride a reverse ratio should be observed ( 1:2, 1:14 and 1:12, respectively). Indeed, it would be interesting to compare the relative proportion of dormant species in real CRP systems with those predicted by these calculations.

\section{Conclusions}


DFT was used to calculate bond dissociation energies for dormant species relevant to RAFT process and compared to those relevant for ATRP. The BDEs, free energies of dissociation and derived equilibrium constants scale in a similar way for both RAFT and ATRP process but there are also significant differences which have their origin in polar effects as well as in steric effects. Thus, tertiary dithioesters cleave relatively easier than the corresponding halides. This correlates well with much better initiation efficiency for $t \mathrm{Bu}$ dithioesters in RAFT than $t \mathrm{Bu}$ halides in ATRP. The relative values of equilibrium constants can be also used to estimate ratios of concentrations of dormant species in copolymerization of various comonomers in several CRP systems. For example, in conventional radical copolymerization of styrene and methyl acrylate, styryl radicals should strongly dominate (200:1). However, for RAFT mediated by dithioacetates, the concentration ratio of acrylate dormant species to styrene dormant species should be $8: 1$, for dithiobenzoates this ratio should be $3: 1$, but for bromide and chloride a ratio 1:14 and 1:12 should be observed respectively.

Acknowledgments. Support from the National Science Foundation (CHE 0405627) and is gratefully acknowledged. R.P. thanks CINES (Montpellier) and CICT (Project CALMIP, Toulouse) for granting free CPU time.

\section{References}

(1) Matyjaszewski, K.; Davis, T. P. Handbook of Radical Polymerization; Wiley-Interscience: Hoboken, 2002.

(2) Matyjaszewski, K.; Spanswick, J. Materials Today 2005, 8, 26-33.

(3) Coessens, V.; Pintauer, T.; Matyjaszewski, K. Progress in Polymer Science 2001, 26, 337-377. 
(4) Davis, K. A.; Matyjaszewski, K. Advances in Polymer Science 2002, 159, 2-166.

(5) Madruga, E. L. Progress in Polymer Science 2002, 27, 1879-1924.

(6) Matyjaszewski, K.; Ziegler, M. J.; Arehart, S. V.; Greszta, D.; Pakula, T. Journal of Physical Organic Chemistry 2000, 13, 775-786.

(7) Matyjaszewski, K., Ed. Advances in Controlled/Living Radical Polymerization; American Chemical Society: Washington, DC, 2003; Vol. 854.

(8) Mori, H.; Mueller, A. H. E. Progress in Polymer Science 2003, 28, $1403-$ 1439.

(9) Goto, A.; Fukuda, T. Progress in Polymer Science 2004, 29, 329-385.

(10) Matyjaszewski, K.; Paik, H.-j.; Zhou, P.; Diamanti, S. J. Macromolecules 2001, 34, 5125-5131.

(11) Matyjaszewski, K.; Xia, J. Chemical Reviews (Washington, D. C.) 2001, 101, 2921-2990.

(12) Matyjaszewski, K. Macromolecules 2002, 35, 6773-6781.

(13) Nanda, A. K.; Matyjaszewski, K. Macromolecules 2003, 36, 1487-1493.

(14) Nanda, A. K.; Matyjaszewski, K. Macromolecules 2003, 36, 599-604.

(15) Nanda, A. K.; Matyjaszewski, K. Macromolecules 2003, 36, 8222-8224.

(16) Singleton, D. A.; Nowlan, D. T., III; Jahed, N.; Matyjaszewski, K.

Macromolecules 2003, 36, 8609-8616.

(17) Wang, J.-S.; Matyjaszewski, K. Journal of the American Chemical Society 1995, 117, 5614-5615.

(18) Wang, J.-S.; Matyjaszewski, K. Macromolecules 1995, 28, 7901.

(19) Pintauer, T.; Braunecker, W.; Collange, E.; Poli, R.; Matyjaszewski, K. Macromolecules 2004, 37, 2679-2682.

(20) Chambard, G.; Klumperman, B.; German, A. L. Macromolecules 2002, 35, $3420-3425$.

(21) Goto, A.; Fukuda, T. Macromol. Rapid Commun. 1999, 20, 633-636.

(22) Le Grognec, E.; Claverie, J.; Poli, R. J. Am. Chem. Soc. 2001, 123, $9513-$ 9524.

(23) Gillies, M. B.; Matyjaszewski, K.; Norrby, P.-O.; Pintauer, T.; Poli, R.; Richard, P. Macromolecules 2003, 36, 8551-8559.

(24) Coote, M. L.; Radom, L. Journal of the American Chemical Society 2003, $125,1490-1491$.

(25) Coote, M. L. Macromolecules 2004, 37, 5023-5031.

(26) Coote, M. L.; Radom, L. Macromolecules 2004, 37, 590-596.

(27) Coote, M. L. J. Phys. Chem. A 2005, 109, 1230- 1239.

(28) Henry, D. J.; Coote, M. L.; Gomez-Balderas, R.; Radom, L. Journal of the American Chemical Society 2004, 126, 1732-1740.

(29) Chiefari, J.; Mayadunne, R. T. A.; Moad, C. L.; Moad, G.; Rizzardo, E.; Postma, A.; Skidmore, M. A.; Thang, S. H. Macromolecules 2003, 36, 2273-2283.

(30) Chong, Y. K.; Krstina, J.; Le, T. P. T.; Moad, G.; Postma, A.; Rizzardo, E.; Thang, S. H. Macromolecules 2003, 36, 2256-2272.

(31) Frisch, M. J.; Trucks, G. W.; Schlegel, H. B.; Scuseria, G. E.; Robb, M. A.; Cheeseman, J. R.; Montgomery, J., J. A.; Vreven, T.; Kudin, K. N.; Burant, J. C.; Millam, J. M.; Iyengar, S. S.; Tomasi, J.; Barone, V.; Mennucci, B.; Cossi, M.; Scalmani, 
G.; Rega, N.; Petersson, G. A.; Nakatsuji, H.; Hada, M.; Ehara, M.; Toyota, K.; Fukuda, R.; Hasegawa, J.; Ishida, M.; Nakajima, T.; Honda, Y.; Kitao, O.; Nakai, H.; Klene, M.; Li, X.; Knox, J. E.; Hratchian, H. P.; Cross, J. B.; Adamo, C.; Jaramillo, J.; Gomperts, R.; Stratmann, R. E.; Yazyev, O.; Austin, A. J.; Cammi, R.; Pomelli, C.; Ochterski, J. W.; Ayala, P. Y.; Morokuma, K.; Voth, G. A.; Salvador, P.; Dannenberg, J. J.; Zakrzewski, V. G.; Dapprich, S.; Daniels, A. D.; Strain, M. C.; Farkas, O.; Malick, D. K.; Rabuck, A. D.; Raghavachari, K.; Foresman, J. B.; Ortiz, J. V.; Cui, Q.; Baboul, A. G.; Clifford, S.;

Cioslowski, J.; Stefanov, B. B.; Liu, G.; Liashenko, A.; Piskorz, P.; Komaromi, I.; Martin, R. L.; Fox, D. J.; Keith, T.; Al-Laham, M. A.; Peng, C. Y.; Nanayakkara, A.; Challacombe, M.; Gill, P. M. W.; Johnson, B.; Chen, W.; Wong, M. W.; Gonzalez, C.; Pople, J. A. Gaussian 03, Revision B.04; Gaussian, Inc.: Pittsburgh PA, 2003.

(32) Perdew, J. P. Physical Review B-Condensed Matter 1986, 33, 8822-8824.

(33) Check, C. E.; Faust, T. O.; Bailey, J. M.; Wright, B. J.; Gilbert, T. M.;

Sunderlin, L. S. Journal of Physical Chemistry A 2001, 105, 8111-8116.

(34) Reed, A. E.; Curtiss, L. A.; Weinhold, F. Chem. Rev. 1988, 88, 899-926.

(35) Coote, M. L.; Henry, D. J. Macromolecules 2005, 38, 1415-1433.

(36) Coote, M. L.; Pross, A.; Radom, L. Organic Letters 2003, 5, 4689-4692.

(37) Beuermann, S.; Buback, M. Progr. Polym. Sci. 2002, 27, 191-254.

(38) Wang, J.-L.; Grimaud, T.; Shipp, D. A.; Matyjaszewski, K.

Macromolecules 1998, 31, 1527-1534.

(39) Shipp, D. A.; Wang, J.-L.; Matyjaszewski, K. Macromolecules 1998, 31, 8005-8008.

(40) Matyjaszewski, K.; Shipp, D. A.; Wang, J.-L.; Grimaud, T.; Patten, T. E. Macromolecules 1998, 31, 6836-6840.

(41) Davis, K. A.; Matyjaszewski, K. Journal of Macromolecular Science, Pure and Applied Chemistry 2004, A41, 449-465.

(42) Coca, S.; Matyjaszewski, K. Macromolecules 1997, 30, 2808-2810.

(43) Coca, S.; Matyjaszewski, K. Journal of Polymer Science, Part A: Polymer Chemistry 1997, 35, 3595-3601.

(44) Moad, G.; Mayadunne, R. T. A.; Rizzardo, E.; Skidmore, M.; Thang, S. H. ACS Symposium Series 2003, 854, 520-535. 